\title{
Development and validation of a quantitative PCR assay for Ichthyophonus spp.
}

\author{
Vanessa C. White ${ }^{1, *}$, J. Frank Morado ${ }^{1}$, Lisa M. Crosson ${ }^{2}$, Brent Vadopalas ${ }^{2}$, \\ Carolyn S. Friedman ${ }^{2}$
}

\begin{abstract}
${ }^{1}$ National Oceanic and Atmospheric Administration, National Marine Fisheries Service, Alaska Fisheries Science Center, Resource Assessment and Conservation Engineering Division, Seattle, Washington 98115, USA

${ }^{2}$ School of Aquatic and Fishery Sciences, College of the Environment, University of Washington, Seattle, Washington 98105, USA
\end{abstract}

\begin{abstract}
Members of the genus Ichthyophonus are trophically transmitted, cosmopolitan parasites that affect numerous fish species worldwide. A quantitative PCR (qPCR) assay specific for genus Ichthyophonus 18S ribosomal DNA was developed for parasite detection and surveillance. The new assay was tested for precision, repeatability, reproducibility, and both analytical sensitivity and specificity. Diagnostic sensitivity and specificity were estimated using tissue samples from a wild population of walleye pollock Theragra chalcogramma. Ichthyophonus sp. presence in tissue samples was determined by qPCR, conventional PCR (CPCR), and histology. Parasite prevalence estimates varied depending upon the detection method employed and tissue type tested. qPCR identified the greatest number of Ichthyophonus sp.-positive cases when applied to walleye pollock skeletal muscle. The qPCR assay proved sensitive and specific for Ichthyophonus spp. DNA, but like $\mathrm{CPCR}$, is only a proxy for infection. When compared to CPCR, qPCR possesses added benefits of parasite DNA quantification and a 100-fold increase in analytical sensitivity. Because this novel assay is specific for known members of the genus, it is likely appropriate for detecting Ichthyophonus spp. DNA in various hosts from multiple regions. However, species-level identification and isotype variability would require DNA sequencing. In addition to distribution and prevalence applications, this assay could be modified and adapted for use with zooplankton or environmental samples. Such applications could aid in investigating alternate routes of transmission and life history strategies typical to members of the genus Ichthyophonus.
\end{abstract}

KEY WORDS: Ichthyophonus sp. $\cdot \mathrm{qPCR} \cdot$ Validation $\cdot$ Detection methods $\cdot$ Theragra chalcogramma Resale or republication not permitted without written consent of the publisher

\section{INTRODUCTION}

Parasites and diseases can have considerable ecological and economic impacts on commercially important fish stocks, including poor product recovery and quality of end products (Kurochkin 1985). Ichthyophonosis, a disease of economic significance in both wild and cultured fisheries (McVicar 1999), is believed to cause mortalities in numerous fish species including yellowtail flounder Limanda ferruginea, rainbow trout Oncorhynchus mykiss, and Atlantic herring Clupea harengus (Sindermann 1958,
Powles et al. 1968, McVicar 1982, Patterson 1996, Rahimian \& Thulin 1996, Mellergaard \& Spanggaard 1997). The effects of ichthyophonosis can vary among hosts, but include reduced swimming stamina, a reduction in mean age, and reduced seafood product quality (McVicar 1999, Hershberger et al. 2002, Kocan et al. 2004). Surveys of Atlantic herring (Sindermann \& Chenoweth 1993) and yellowtail flounder (Powles et al. 1968, Ruggieri et al. 1971) have documented epizootics in the North Atlantic. However, in regions of the North Pacific, ichthyophonosis is considered to be an emerging disease 
affecting Chinook salmon O. tshawytscha (Kocan et al. 2004), Pacific herring C. pallasii (Marty et al. 1998), and walleye pollock Theragra chalcogramma (Eaton et al. 1991).

Ichthyophonosis is caused by protists of the genus Ichthyophonus in the class Mesomycetozoea, a group located at the divergence between animals and fungi (Mendoza et al. 2002). Two species exist within this genus, viz. the type species $I$. hoferi, described over a century ago (Plehn \& Mulsow 1911), and I. irregularis, characterized more recently (Rand et al. 2000). Although the majority of worldwide reports from this genus have been identified as I. hoferi, there are indications that this species may represent a species assemblage of closely related organisms (Spanggaard et al. 1996, Rasmussen et al. 2010). Phylogenetic studies aim to further define this species complex, which may provide insight into phenotypic differences among isolates and challenge the notion of broad global distribution of this single species (Criscione et al. 2002, Rasmussen et al. 2010).

Ichthyophonus spp. infections can be detected by a number of diagnostic methods including, but not limited to, in vitro culture, histology, and conventional PCR (cPCR) (McVicar 1982, Whipps et al. 2006). In vitro explant culture (McVicar 1982, Kocan et al. 2004 ) is likely the most accurate detection technique for determining infection prevalence (Kocan et al. 2011) but is neither quantitative nor suitable for use at remote collection sites that fail to satisfy the requirement of a temperature-controlled environment. For Ichthyophonus spp., in vitro culture alone is not appropriate for detection in environmental samples, as morphologically similar species could be present, yielding false positive results.

Histology, like in vitro culture, provides visual confirmation of the organism but also provides information on host response to the parasite and allows for long-term storage (Rahimian 1998). Spherical bodies associated with infection, often called schizonts (previously 'resting spores'), are the most commonly observed stage in infected tissue (McVicar 1999, Kocan et al. 2010). Spherical schizonts vary in diameter from 10 to $250 \mu \mathrm{m}$ and are multinucleated (McVicar 1999). Histology provides visual identification via microscopy; however, it is less sensitive than in vitro culture (Whipps et al. 2006). Therefore, detection of Ichthyophonus spp. by histology alone may yield false negative results, resulting in significant underestimates of parasite prevalence, especially in early infections and related to the patchy nature of schizont distribution within the host tissues (Kocan et al. 2011).
Whipps et al. (2006) developed and evaluated a CPCR assay for Ichthyophonus hoferi DNA as a tool to detect the presence of parasite DNA from preserved host tissues while also allowing for long-term sample storage. These authors demonstrated that the diagnostic specificity of the test was consistently greater than $94 \%$ regardless of infection intensity, while the diagnostic sensitivity of the test was much higher in fish with heavy infections than those with light infections (Whipps et al. 2006). Although Whipps et al. (2006) demonstrated that cPCR is a specific (94.0-100\%) and moderately sensitive $(47.8-100 \%)$ tool for detecting I. hoferi DNA, in vitro culture is still considered the most accurate technique for determining the best estimate of parasite prevalence (Kocan et al. 2011).

With advances in molecular biology, quantitative PCR (qPCR) has become a routine technique for pathogen detection and surveillance (Guimaraes et al. 2011). Because qPCR can quantify parasite DNA, such assays have the potential for enabling fine-scale pathogen monitoring within host species as well as in the environment (Guy et al. 2003, Guimaraes et al. 2011) while increasing through-put by obviating gel visualization needed for conventional molecular methods. Moreover, qPCR has greater analytical sensitivity than CPCR (Guimaraes et al. 2011) and could potentially detect more light infections, resulting in better estimates of prevalence. However, because both qPCR and cPCR target parasite DNA and do not visualize the parasite, these assays are a proxy indicator of parasite presence and require extensive developmental testing to ensure assay validity (Burreson 2008, Bustin et al. 2009). A qPCR assay may prove useful for Ichthyophonus spp. detection in novel hosts, putative transport hosts, and the environment, thus elucidating transmission, life history, and disease dynamics of this parasite, and assisting fisheries management. Therefore, the objectives of this study were to develop, optimize, and validate a qPCR assay for quantification of Ichthyophonus spp. DNA and contrast molecular and histological methods of parasite detection using an infected wild fish population, Alaskan walleye pollock.

\section{MATERIALS AND METHODS}

\section{Host samples}

In 2006 and 2007 between the months of June and July, walleye pollock were captured using bottom trawl gear during National Marine Fisheries Service annual stock assessment surveys in Alaska (USA) wa- 
ters. Individuals collected in $2006(\mathrm{~N}=83)$ had a mean fork length of $55.2 \mathrm{~cm}$ (range 17-79 cm); in 2007 ( $\mathrm{N}=$ 221) mean fork length was $48.3 \mathrm{~cm}$ (range 9-84 cm).

Two to 6 individuals were collected daily, and the weight, length, and sex of each were recorded. Fish remained on the boat deck at ambient temperature for approximately $1 \mathrm{~h}$ prior to sample collection (monthly average air temperature range was 5 to $9^{\circ} \mathrm{C}$ for collection months). Two tissues were excised from each fish: a portion of the ventricle of the heart and skeletal muscle near the dorsal fin (mainly white muscle within Sector 2 defined by Kocan et al. 2011). Each tissue type was removed with a separate set of clean tools, split into 2 samples, and preserved separately in $10 \%$ sodium acetate-buffered formaldehyde for histological processing and 100\% ethanol for qPCR development and molecular analysis. Tool sets used on the boat were scrubbed with warm soapy water, soaked in $10 \%$ bleach, rinsed with fresh water, and allowed to air-dry.

\section{Ichthyophonus spp.-specific qPCR development and validation}

\section{DNA extraction}

Ethanol-preserved tissue samples were cut into quarters with a sterile scalpel; one-quarter of the tissue was minced and ca. $20 \mathrm{mg}$ were used per extraction. Residual ethanol was allowed to evaporate on the bench (ca. $10 \mathrm{~min}$ ). Between samples, tools were wiped with a Kimwipe, dipped in $10 \%$ bleach, and rinsed in tap water twice, and then the tools were rinsed in deionized water and dipped in alcohol and flamed twice. DNA was extracted from each minced sample using a DNeasy Blood \& Tissue kit (Qiagen) following the manufacturer's protocol, except that DNA was eluted in $100 \mu l$.

\section{Primer and probe design and optimization}

ClustalX 2.0 (Larkin et al. 2007) was used to align published $18 \mathrm{~S}$ ribosomal DNA (rDNA) sequences of members of the genus Ichthyophonus from multiple hosts from various regions and other related species (Table 1). Prospective primers and hydrolysis probes were designed using Primer3 0.4.0 (Rozen \& Skaletsky 2000) based on all Ichthyophonus spp. 18S rDNA sequences publically available at the time of development (Table 1) and the consensus sequence of 10 clones of Ichthyophonus sp. 18S rDNA extracted from one walleye pollock host (GenBank accession no. JX509908-JX509918). Primer-probe sets were evaluated during assay development for specificity, dynamic range, efficiency, and correlation coefficient (Stratagene 2004). The primer-probe set vc7F-ICH27-vc5R (Table 2), yielding a 75 bp qPCR amplicon, was selected for further assay development. The hydrolysis probe was labeled with 6-FAM on the $5^{\prime}$ end and the quencher Iowa Black FQ on the 3' end (Integrated DNA Technologies).

Annealing temperature was optimized using a gradient thermal cycler from 54 to $66^{\circ} \mathrm{C}$ (Eppendorf Mastercycler). Primer concentrations were optimized by testing 5 concentrations $(50,100,300,400$, and

Table 1. Species and accession numbers used in sequence alignment of members of the genus Ichthyophonus and other related species; geographical region of host species included for Ichthyophonus spp.

\begin{tabular}{|c|c|c|}
\hline Species & Host & GenBank accession no. \\
\hline \multicolumn{3}{|l|}{ Pacific Ocean North America } \\
\hline Ichthyophonus sp. & $\begin{array}{l}\text { Theragra } \\
\text { chalcogramma }\end{array}$ & JX509908-JX509918 \\
\hline Ichthyophonus hoferi & Clupea pallasii & AF467793-AF467798 \\
\hline Ichthyophonus hoferi & $\begin{array}{r}\text { Oncorhynchus } \\
\text { tshawytscha }\end{array}$ & AF467799-AF467802 \\
\hline Ichthyophonus hoferi & Sebastes flavidus & AF467785-AF467786 \\
\hline Ichthyophonus hoferi & Sebastes alutus & AF467787-AF467792 \\
\hline \multicolumn{3}{|l|}{ Atlantic Ocean North America } \\
\hline Ichthyophonus hoferi & Limanda ferruginea & U25637 \\
\hline Ichthyophonus irregularis & Limanda ferruginea & AF232303 \\
\hline \multicolumn{3}{|l|}{ Atlantic Ocean Northern Europe } \\
\hline Ichthyophonus hoferi & Clupea harengus & $\mathrm{U} 43712$ \\
\hline \multicolumn{3}{|l|}{ Related species } \\
\hline Uncultured ichthyosporean & & HQ219472 \\
\hline Amoebidium parasiticum & & $\mathrm{AF} 274051$ \\
\hline Enterobryus sp. CMJ-2003 & & AY336701 \\
\hline Paramoebidium sp. CMJ-2003 & & AY336708 \\
\hline Sphaeroforma arctica & & Y16260 \\
\hline Creolimax fragrantissima & & EU124916 \\
\hline Pseudoperkinsus tapetis & & AF192386 \\
\hline Dermocystidium sp. CM-2002 & & AF533950 \\
\hline Anurofeca richardsi & & $\mathrm{AF} 070445$ \\
\hline Rhinosporidium seeberi & & AF118851 \\
\hline Amphibiocystidium viridescens & & EF493029 \\
\hline Sphaerothecum destruens & & AY267344 \\
\hline Psorospermium haeckeli & & PHU33180 \\
\hline Capsaspora owczarzaki & & AY363957 \\
\hline
\end{tabular}


Table 2. Primers and probes used in development and validation of the Ichthyophonus spp. quantitative PCR (qPCR) assay

\begin{tabular}{|llll|}
\hline Purpose & Type & Name & Sequence \\
\hline qPCR assay & Probe & ICH27 & $\begin{array}{l}\text { 5'-/6-FAM/ TAA GAG CAC CCA CTG CCT TCG AGA } \\
\text { AGA /IABLFQ/-3' }\end{array}$ \\
qPCR assay & Forward primer & vc7F & $5^{\prime}$-GTC TGT ACT GGT ACG GCA GTT TC-3' \\
qPCR assay & Reverse primer & vc5R & $5^{\prime}$-TCC CGA ACT CAG TAG ACA CTC AA-3' \\
Plasmid template & Forward primer & PIchF1 & $5^{\prime}$-ACC CGA CTT CTG GAA GGG TTG-3' \\
Plasmid template & Reverse primer & PIchR3 & 5'-AGT ATG TGT TGC CAC GCG CT-3' \\
\hline
\end{tabular}

$600 \mathrm{nM}$ ) in a $5 \times 5$ full factorial matrix format. Hydrolysis probe concentration was optimized using 100, 200, and 300 nM per reaction. Optimal concentrations were defined as those yielding the lowest quantification cycle (Cq) (Stratagene 2004).

\section{qPCR conditions}

qPCR reactions were prepared in $25 \mu \mathrm{l}$ volumes consisting of $2 \mu \mathrm{l}$ of extracted DNA template, Ichthyophonus spp.-specific primers and probe (400 nM vc7F and vc5R primers, 300 nM 6-FAM-labeled probe ICH27), $15 \mu \mathrm{g}$ bovine serum albumin, $12.5 \mu \mathrm{l}$ $2 \times$ SensiMix II Probe (Bioline), and $6.25 \mu \mathrm{l}$ sterile deionized $\mathrm{H}_{2} \mathrm{O}$; during development, $2 \mu$ deionized $\mathrm{H}_{2} \mathrm{O}$ were replaced with exogenous internal amplification control (IAC) primers, HEX-labeled probe, and template (Nolan et al. 2006) to test for inhibition. Each 96-well reaction plate was comprised of serially diluted standards in triplicate, unknown samples in duplicate, and 6 no-template controls (NTC). The qPCR assay was conducted on an Mx3000Pтм RealTime PCR System (Agilent Technologies) and a CFX96 ${ }^{\text {TM }}$ Real-Time PCR Detection System (Bio-Rad Laboratories) using the manufacturers' softwares. On both instruments, Taq was activated for $10 \mathrm{~min}$ at $95^{\circ} \mathrm{C}$, followed by 40 amplification cycles at $95^{\circ} \mathrm{C}$ for $30 \mathrm{~s}, 60^{\circ} \mathrm{C}$ for $1 \mathrm{~min}$, and $72^{\circ} \mathrm{C}$ for $1 \mathrm{~min}$.

\section{Plasmid standard curve}

During assay development, PCR primers PIchF1 and PIchR3 (Table 2) were used to amplify a $1530 \mathrm{bp}$ fragment of Ichthyophonus sp. (from walleye pollock) 18S rDNA for insertion into a plasmid. 'Fragment B' (generated by primers ICH1F and ICH4R; Criscione et al. 2002) is nested within the $1530 \mathrm{bp}$ fragment and is also suitable for use as a plasmid insert for the qPCR assay. Each fragment was purified (QIAquick PCR Purification Kit; Qiagen), inserted into a
pCR®2.1-TOPO® plasmid vector, and cloned in TOP10 Escherichia coli (TOPO-TA Cloning ${ }^{\circledR}$ Kit; Invitrogen) according to the manufacturers' protocols. Recombinant plasmid DNA was purified (QIAprep Spin Miniprep Kit; Qiagen) and digested with the restriction enzyme Not 1 to linearize the plasmid. The plasmid was quantified relative to standards (dsDNA Quantitation Kit; Invitrogen) using a microplate reader (Tecan); a stock solution of $1.5 \times$ $10^{7}$ plasmid copies $\mu l^{-1}$ was prepared following the methods of Applied Biosystems (2003). The final plasmid standard curve consisted of seven 10-fold dilutions in Tris EDTA buffer (TE).

\section{qPCR efficiency and linear dynamic range}

Two separate plasmids were assembled (insert generated with primers PIchF1/PIchR3), and a standard curve was constructed from each of the 2 plasmids as described above. Dilution series from each plasmid containing 3 to $3 \times 10^{6}$ copies reaction $^{-1}$ were assayed in triplicate on 2 different plates with extra replicates for low copy number standards (20 replicates of 3 copies and 10 replicates of 30 copies). Efficiency $(E)$ was calculated from the slope of the standard curve using the following formula $E=$ $\left[10^{(-1 / \text { slope })}\right]-1$; efficiencies between 90 and $110 \%$ were considered acceptable (Stratagene 2004). Standard curve precision was evaluated via coefficients of determination $\left(\mathrm{R}^{2}\right)$; an $\mathrm{R}^{2}$ value greater than 0.985 was considered acceptable (Stratagene 2004). The linear dynamic range was determined by plotting $\mathrm{Cq}$ versus the dilution factor of the standard curve in a base10 semi-logarithmic graph, fitting the data to a straight line. The linear range of the plot is the dynamic range of the qPCR assay. Regression coefficients were compared following a statistical test outlined by Burns et al. (2005) to calculate the probability that differences between 2 coefficients are due to chance alone. Briefly, an F-variance ratio test was used; the null hypothesis assumes no significant 
difference between 2 regression coefficients and p-values $<0.05$ reject the null hypothesis (Burns et al. 2005).

Reproducibility and repeatability

Eight Ichthyophonus sp. positive walleye pollock samples were selected (4 heart muscle, 4 skeletal muscle), with Ichthyophonus sp. DNA concentrations spanning the operating range of the assay as described by OIE (2009). These 8 walleye pollock were identified as Ichthyophonus sp.-positive by both histology and qPCR. Data were collected for each sample, and an average percent coefficient of variation (CV) was calculated per tissue type.

To test reproducibility, samples and the plasmid standard curve were assayed on a plate in triplicate once per day for $5 \mathrm{~d}$ and were performed by 3 different operators. Reproducibility, or inter-assay variation, was determined for each sample by calculating CV of copy number sample means between runs (Bustin et al. 2009). CV was determined using the following calculation where 'plate mean' is the mean of triplicate reactions for each sample per plate, '5 d mean' is the mean of the plate means over $5 \mathrm{~d}$, and $\mathrm{SD}$ is the standard deviation of the $5 \mathrm{~d}$ mean:

$$
\frac{\mathrm{SD}}{5 \mathrm{~d} \text { mean }} \times 100=\% \mathrm{CV}
$$

In general, a mean inter-assay variability of 15 to $30 \%$ is realistic over a wide dynamic range (Pfaffl 2004).

To test repeatability, 8 replicates of each sample were assayed on 1 plate with the plasmid standard curve in triplicate. Repeatability, or intra-assay variation, was determined by calculating the percent CV for each sample using the following formula where 'plate mean' is the mean copy number of the 8 replicates, and SD is the standard deviation of the plate mean (Bustin et al. 2009):

$$
\frac{\mathrm{SD}}{\text { Plate mean }} \times 100=\% \mathrm{CV}
$$

Generally, a CV of 10 to $20 \%$ is realistic for mean intra-assay variability (Pfaffl 2004).

\section{Analytical sensitivity and specificity}

The limit of detection, or analytical sensitivity (ASe), is the point where the assay measurement can no longer be considered valid due to loss of signal.
ASe is defined as the lowest number of plasmid copies giving $50 \%$ positive results (OIE 2009). Replicates $(\mathrm{N}=60-80)$ of low copy plasmid standards $(1,3$, and 10 copies) from several plasmid standard curves were assayed on multiple plates over multiple days to determine the assay's ASe.

Analytical specificity (ASp) was evaluated at the genus level by measuring 3 component factors, i.e. selectivity, exclusivity, and inclusivity (OIE 2010), to determine the assay's ability to distinguish between Ichthyophonus spp. DNA and other assay components. Selectivity refers to the assay's ability to accurately quantify the DNA target in the presence of sample matrix interferents (OIE 2010). To confirm assay selectivity, one plasmid was used to construct multiple standard curves in 3 diluents, i.e. TE, DNA extracted from walleye pollock heart tissue, and DNA extracted from walleye pollock skeletal muscle. Each standard curve was assayed in triplicate to determine whether qPCR efficiency and precision were within acceptable ranges, 90 to $110 \%$ and $>0.985$, respectively (Stratagene 2004). Each standard curve in DNA diluents was assayed on the same plate paired with a standard curve in TE to compare regression coefficients following Burns et al. (2005). Additionally, an IAC (Nolan et al. 2006) was multiplexed in a subset of reactions to determine whether PCR amplification was inhibited (increased or absent Cq). Exclusivity at the genus level refers to the ability of the assay to detect genomic sequence unique to known members of the genus Ichthyophonus while excluding other potentially cross-reactive organisms (OIE 2010). Exclusivity was assessed by performing the qPCR assay with Ichthyophonus sp. DNA from walleye pollock and DNA from other non-Ichthyophonus spp. members of the class Ichthyosporea including Creolimax fragantissima, Dermocystidium salmonis, Pirum gemmata, Sphaerothecum destruens, and Sphaeroforma nootkatensis acquired from W. Marshall (University of British Columbia, Canada). To confirm the presence of Ichthyosporea material, each donated sample was assayed by cPCR with both ascomycete universal primers (SL1/CITS5; Kohlmeyer et al. 2005) and 18S rDNA universal primers (CS1/CAS2; Le Roux et al. 1999), as neither universal primer set was appropriate for all species tested. Inclusivity at the genus level, or the ability of this assay to detect several strains and species within the genus Ichthyophonus, was tested in silico using Amplify 3.1 (http://engels.genetics.wisc.edu/amplify/) on DNA sequences of all published isotypes of Ichthyophonus spp. 


\section{Diagnostic sensitivity and specificity}

Preliminary estimates of diagnostic sensitivity (DSe) and specificity (DSp) were calculated following the work of Whipps et al. (2006). Heart and skeletal muscle tissues were tested for Ichthyophonus sp. presence using 2 existing methods: histology and CPCR. The 'true' infection status of a fish was determined by using a combination of these test results. A fish was categorized as 'infected' with Ichthyophonus sp. if either of the tissues tested positive with either test; a fish was categorized as 'uninfected' if all test results were negative. Ichthyophonus sp. infections were also categorized as light or heavy. Light infections were characterized as having only 1 tissue type positive and $\leq 1$ schizont $\mathrm{mm}^{-2}$ of tissue by histology. Heavy infections where characterized as having $>1$ tissue type infected and $>1$ schizont $\mathrm{mm}^{-2}$ tissue identified by histology (Whipps et al. 2006). To calculate DSe and DSp, 'true' infection status and qPCR results (skeletal muscle, heart, and tissues combined) were organized in cross-classification table format.

\section{cPCR-18S rDNA universal and Ichthyophonus hoferi-specific}

To confirm the presence of amplifiable DNA extracted from each fish sample, a cPCR reaction was performed with 18S rDNA eukaryotic universal primers (CS1/CAS2; Le Roux et al. 1999). Reactions were prepared in $20 \mu \mathrm{l}$ volumes and consisted of $1 \times$ GoTaq Flexi PCR buffer (Promega), $2.5 \mathrm{mM} \mathrm{MgCl}_{2}$, $0.2 \mathrm{mM}$ dNTP, $25 \mathrm{pmol}$ of each primer, $0.025 \mathrm{U} \mathrm{Hl}^{-1}$ Taq DNA polymerase, and $0.8 \mu \mathrm{l}$ of template DNA. Reactions were carried out using an MJ Research DNA Engine PTC-200 thermal cycler, with initial denaturation for $5 \mathrm{~min}$ at $94^{\circ} \mathrm{C}$, followed by 30 amplification cycles of $1 \mathrm{~min}$ at $94^{\circ} \mathrm{C}, 1 \mathrm{~min}$ at $55^{\circ} \mathrm{C}$, and $1 \mathrm{~min}$ at $72^{\circ} \mathrm{C}$, followed by final adenylation at $72^{\circ} \mathrm{C}$ for 10 min. All DNA samples and the plasmid standard curve were tested with an $I$. hoferi-specific CPCR assay using primers Ich7f and Ich6r, following published methods (Whipps et al. 2006). PCR products were separated by electrophoresis on 1 to $2 \%$ agarose gels, stained with ethidium bromide, and visualized using UV illumination.

\section{Histology}

Formalin-fixed tissues of heart and skeletal muscle were processed through paraffin blocks follow- ing standard procedures (Sheehan \& Hrapchak 1980). Deparaffinized tissue sections were stained with hematoxylin and eosin Y (Luna 1968). The entire section of each tissue type was examined by light microscopy, and image analysis was performed using Nikon-Elements BR 3.0 software. Tissue area $\left(\mu \mathrm{m}^{2}\right)$ was first estimated using the calibrated auto-detect function. The same function was used to enumerate and estimate the area of Ichthyophonus sp. and associated granulomas within the tissue. These data were used to calculate the number and size distribution of schizonts per tissue area and compare histological results to qPCR copy number. Ichthyophonus sp. schizont area $\left(\mu \mathrm{m}^{2}\right)$ was normalized by natural log transformation, and estimates of diameter were calculated based on schizonts being circular, although it is recognized that most observed individuals were not perfect circles due to histological processing.

\section{RESULTS}

\section{Ichthyophonus spp.-specific qPCR development and validation}

qPCR efficiency and linear dynamic range

Regression coefficients of 2 plasmid standard curves assayed on 2 separate plates were not significantly different (Table 3). Both mean (99.3\%) and individual reaction efficiencies of plasmid standard curves used for determining dynamic range were within the acceptable range of 90 to $110 \%$; both mean (0.993) and individual assay precision based on coefficient of determination were greater than the acceptable limit of 0.985 (Table 3). Based on the reaction efficiency of multiple standard curves, the linear dynamic range of the assay was 3 to $3 \times 10^{6}$ copies.

Reproducibility and repeatability

The assay was reproducible. Mean inter-assay variability of copy number (CV) was $9.4 \%$ for skeletal muscle samples and $11.2 \%$ for heart muscle samples; for both sample types, variability was less than the goal of 15 to $30 \%$. The mean intra-assay variability or repeatability of the qPCR assay was $8.2 \%$ for skeletal muscle samples and $11.2 \%$ for heart muscle samples, also within or below the target range for intra-assay variability of 10 to $20 \%$ (Table 4 ). 
Table 3. Ichthyophonus spp. Quantitative PCR (qPCR) assay efficiency and precision of plasmid standard curves prepared in different diluents for (a) preliminary standard curve development, where 20 replicates were performed for 3-copy standards, 10 replicates for 30-copy standards, and 3 replicates for all other standards; (b) selectivity component of analytical specificity, where 3 replicates were performed for all standards. The linear range for all plasmid standard curves is 3 to $3 \times 10^{6}$ copies

\begin{tabular}{|llrr|}
\hline $\begin{array}{l}\text { Standard curve } \\
\text { comparison }\end{array}$ & Diluent (ng DNA reaction $\left.{ }^{-1}\right)$ & $\begin{array}{c}\text { Efficiency } \\
(\%)\end{array}$ & $\begin{array}{c}\text { Precision } \\
\left(\mathrm{R}^{2}\right)\end{array}$ \\
\hline $\begin{array}{l}\text { (a) Multiple plasmid prepara- } \\
\text { tions in standard diluent }\end{array}$ & Tris EDTA buffer-plasmid 1 & 0.993 \\
(b) Single plasmid preparation & Tris EDTA buffer-plasmid 2 & 100.5 & 0.993 \\
$\quad$ Tris EDTA buffer & 98.1 & 0.651 \\
in different diluents to test & Extracted skeletal muscle DNA (88) & 94.8 & 0.997 \\
& Tris EDTA buffer & 94.8 & 0.995 \\
& Extracted heart DNA (172) & 100.0 & 0.997 \\
& Tris EDTA buffer & 99.1 & 0.996 \\
& Extracted heart DNA (48) & 100.4 & 0.994 \\
& & & 0.995 \\
\hline
\end{tabular}

Table 4. Theragra chalcogramma. Reproducibility (inter-assay variation) and repeatability (intra-assay variation) of the Ichthyophonus spp.-specific quantitative PCR (qPCR) assay for a range of walleye pollock skeletal and heart muscle tissue

\begin{tabular}{|c|c|c|c|c|c|c|}
\hline \multirow{2}{*}{ Sample ID no. } & \multirow[b]{2}{*}{ Mean copies } & \multirow{2}{*}{$\begin{array}{c}\text { Reproducibility } \\
\text { SD }\end{array}$} & \multirow[b]{2}{*}{ CV (\%) } & \multirow[b]{2}{*}{ Mean copies } & \multirow{2}{*}{$\begin{array}{c}\text { Repeatability } \\
\text { SD }\end{array}$} & \multirow[b]{2}{*}{ CV $(\%)$} \\
\hline & & & & & & \\
\hline \multicolumn{7}{|l|}{ Muscle } \\
\hline $2007-4133 c$ & $2.51 \times 10^{1}$ & $2.95 \times 10^{0}$ & 11.7 & $2.57 \times 10^{1}$ & $4.16 \times 10^{0}$ & 16.2 \\
\hline $2007-4202 \mathrm{C}$ & $3.67 \times 10^{2}$ & $1.80 \times 10^{1}$ & 4.9 & $3.63 \times 10^{2}$ & $2.35 \times 10^{1}$ & 6.5 \\
\hline $2006-1024 \mathrm{C}$ & $8.54 \times 10^{3}$ & $1.32 \times 10^{3}$ & 15.4 & $8.65 \times 10^{3}$ & $4.11 \times 10^{2}$ & 4.8 \\
\hline \multirow{2}{*}{$2006-1028 c$} & $3.69 \times 10^{4}$ & $2.08 \times 10^{3}$ & 5.6 & $3.84 \times 10^{4}$ & $2.06 \times 10^{3}$ & 5.4 \\
\hline & & Mean & 9.4 & & Mean & 8.2 \\
\hline \multicolumn{7}{|l|}{ Heart } \\
\hline 2006-1066d & $1.19 \times 10^{1}$ & $1.50 \times 10^{0}$ & 12.5 & $1.43 \times 10^{1}$ & $2.57 \times 10^{0}$ & 18.0 \\
\hline $2007-4103 d$ & $2.30 \times 10^{2}$ & $2.21 \times 10^{1}$ & 9.6 & $2.36 \times 10^{2}$ & $3.81 \times 10^{1}$ & 16.2 \\
\hline $2006-1034 d$ & $3.20 \times 10^{3}$ & $5.34 \times 10^{2}$ & 16.7 & $3.23 \times 10^{3}$ & $1.98 \times 10^{2}$ & 6.1 \\
\hline \multirow[t]{2}{*}{$2007-4145 d$} & $3.73 \times 10^{4}$ & $2.29 \times 10^{3}$ & 6.1 & $3.45 \times 10^{4}$ & $1.54 \times 10^{3}$ & 4.5 \\
\hline & & Mean & 11.2 & & Mean & 11.2 \\
\hline
\end{tabular}

\section{Analytical sensitivity and specificity}

By OIE definition (OIE 2009), the ASe was 1 copy per reaction. The ability to detect low copy numbers ranged from $50 \%(40 / 80)$ for 1 copy, $80.8 \%(59 / 73)$ for 3 copies, and $100 \%(60 / 60)$ for 10 copies. However, the lowest limit of detection theoretically possible has been defined as 3 copies (Bustin et al. 2009). Consequently, we set the ASe of this assay to 3 copies, and unknowns were considered positive only if the average quantity of replicates was $\geq 3$ copies.

ASp was defined by the selectivity, exclusivity, and inclusivity of the assay. Selectivity: For a linear range of 3 to $3 \times 10^{6}$ copies, efficiency and precision of plasmid standard curves prepared in different diluents were similar to standard curves prepared in TE (absence of matrix interferents) and within the acceptable ranges of 90 to $110 \%$ and $>0.985$, respectively (Table 3 ). The presence of walleye pollock heart and skeletal muscle extracted DNA with con- centrations up to $172 \mathrm{ng}$ per reaction did not measurably inhibit the assay (Table 3). The IAC (Nolan et al. 2006) Cq range was consistently less than $1.5 \mathrm{Cq}$ and did not increase in the presence of sample matrix relative to no template controls. Exclusivity: Ichthyophonus sp. from walleye pollock was tested in vitro, while all other isotypes and species within the genus Ichthyophonus were tested in silico. Only DNA from the genus Ichthyophonus was amplified with the qPCR assay, illustrating its genus-level specificity. The presence of amplifiable DNA was confirmed in samples of the other tested members of the class Ichthyosporea using universal primers. Although Amoebidium parasiticum (GenBank accession no. AF274051) and an uncultured ichthyosporean clone (GenBank accession no. HQ219472.1) have the highest sequence similarity with Ichthyophonus spp. in the regions selected for the qPCR primers, neither was available to test for cross-reactivity in vitro, but no PCR amplicon was predicted based on in silico 
PCR. Inclusivity: Based on tests performed in silico on published sequences of Ichthyophonus spp., we expect the qPCR assay to detect DNA from all known isotypes of members of the genus Ichthyophonus. With the exception of the isotype associated with the North Pacific rockfishes Sebastes alutus and S. flavidus, all sequences of published isotypes (GenBank search date 3 January 2013) are identical in the qPCR amplicon region. Therefore, this qPCR assay is likely appropriate for Ichthyophonus spp. DNA detection in various hosts worldwide, including mugilids from the Mediterranean, Clupea harengus from the European Atlantic, Alosa sapidissima and Limanda ferruginea from the North American Atlantic, freshwater rainbow trout from Idaho, and C. pallasii, Oncorhynchus tshawytscha, A. sapidissima, Theragra chalcogramma, and copper rockfish from the North American Pacific. The isotype associated with the North Pacific rockfishes $S$. alutus and $S$. flavidus varies by a single nucleotide in the forward primer sequence, $\mathrm{vc7F}$; these isotypes would require testing in vitro to ensure inclusivity and await further examination. Because this assay is specific for members of the genus Ichthyophonus, specific molecular identification of isotypes and species would require sequencing.

\section{Diagnostic sensitivity and specificity}

Preliminary estimates of DSe and DSp following the methods of Whipps et al. (2006) are listed in Table 5. DSp was high $(\geq 93.8 \%)$ regardless of tissue type, year, or infection level. DSe was $\geq 63.8 \%$ regardless of tissue type and year but varied greatly depending on infection level, with values ranging from 36 to $100 \%$ (Table 5). DSe was highest for any infection level when the qPCR assay was performed as a 2-tissue test (Table 5). For all detection methods, tests performed on skeletal muscle yielded more positive results than heart tissue (Table 6). Prevalence of Ichthyophonus sp. in walleye pollock in 2006 and 2007 was 27.7 and $23.5 \%$, respectively, when all test results were combined, but prevalence estimations varied depending on detection method and tissue tested (Table 6).

\section{CPCR-18S rDNA universal and Ichthyophonus hoferi-specific}

All extracted fish samples produced a PCR product when assayed with 18S rDNA universal primers, indicating the presence of amplifiable DNA. Ichthyophonus sp. DNA was detected in walleye pollock by CPCR (Whipps et al. 2006). Concordance between the molecular assays was observed, as all fish samples that were scored negative by the new qPCR assay were also scored negative for parasite DNA by the cPCR assay of Whipps et al. (2006) from the same extraction. Of the 112 fish samples (skeletal muscle or heart) that were identified as positive by the qPCR assay, 66 (59\%) were positive by CPCR. Samples with low copy number ( $<300$ copies) were less likely to be

Table 5. Theragra chalcogramma. Diagnostic sensitivity (DSe) and specificity (DSp) of the Ichthyophonus spp. quantitative PCR (qPCR) test on skeletal muscle, heart tissue, and the 2 tissues combined for identification of parasite DNA in walleye pollock. DSe was calculated for light and heavy infections separately following Whipps et al. (2006). Values are percentages (95\% binomial proportion CI)

\begin{tabular}{|c|c|c|c|c|}
\hline \multirow{2}{*}{$\begin{array}{l}\text { Tissue } \\
\text { Year }\end{array}$} & \multirow[b]{2}{*}{ Combined results } & \multicolumn{2}{|l|}{ Sensitivity } & \multirow{2}{*}{ Specificity } \\
\hline & & Light & Heavy & \\
\hline \multicolumn{5}{|c|}{ Skeletal muscle } \\
\hline 2006 & $73.7(54-93)$ & $54.5(25-84)$ & $100(75-100)$ & $93.8(88-100)$ \\
\hline 2007 & 91.5 (84-99) & $88.0(75-100)$ & $95.5(87-100)$ & $98.3(96-100)$ \\
\hline \multicolumn{5}{|l|}{ Heart } \\
\hline 2006 & 73.7 (54-93) & $54.5(25-84)$ & $100(75-100)$ & $98.4(95-100)$ \\
\hline 2007 & $63.8(50-78)$ & $36.0(17-55)$ & $95.5(87-100)$ & $98.2(96-100)$ \\
\hline \multicolumn{5}{|c|}{ Combined (2-tissue test) } \\
\hline 2006 & $94.7(85-100)$ & $90.9(74-100)$ & $100(75-100)$ & $93.8(88-100)$ \\
\hline 2007 & $95.7(90-100)$ & $92.0(81-100)$ & $100(89-100)$ & 97.1 (95-100) \\
\hline
\end{tabular}

Table 6. Ichthyophonus sp. infecting Theragra chalcogramma. Prevalence in walleye pollock tissues as determined by 3 detection methods. Values are no. fish positive/no. fish examined (\% positive; $95 \%$ binomial proportion CI). CPCR: conventional PCR; qPCR: quantitative PCR

\begin{tabular}{|lcc|}
\hline $\begin{array}{l}\text { Detection method } \\
\text { Tissue }\end{array}$ & 2006 & 2007 \\
\hline Histology & & \\
$\quad$ Skeletal muscle & $14 / 83(16.9 ; 8.8-24.9)$ & $36 / 221(16.3 ; 11.4-21.2)$ \\
Heart & $4 / 83(4.8 ; 0.2-9.4)$ & $22 / 219(10.0 ; 6.1-14.0)$ \\
cPCR & & \\
Skeletal muscle & $12 / 83(14.5 ; 6.9-22.0)$ & $29 / 221(13.1 ; 8.7-17.6)$ \\
Heart & $9 / 83(10.8 ; 4.2-17.5)$ & $16 / 218(7.3 ; 3.9-10.8)$ \\
qPCR & $18 / 83(21.7 ; 12.8-30.6)$ & $46 / 221(20.8 ; 15.5-26.2)$ \\
Skeletal muscle & $15 / 83(18.1 ; 9.8-26.4)$ & $33 / 218(15.1 ; 10.4-19.9)$ \\
Heart & $23 / 83(27.7 ; 18.1-37.3)$ & $51 / 217(23.5 ; 17.9-29.1)$ \\
All tests combined ${ }^{\text {a }}$ & & \\
aOnly included fish when results were available for all tests \\
\hline
\end{tabular}






Fig. 1. Theragra chalcogramma. Proportion of quantitative PCR (qPCR) positive tissue samples from walleye pollock found positive with conventional PCR (CPCR). Groups arranged by decreasing Ichthyophonus sp. DNA starting quantity, estimated by qPCR. K: ×1000

detected by the cPCR method (Fig. 1), illustrating the improved sensitivity of the qPCR assay. Similarly, CPCR results from the plasmid standard curve produced a faint band for the 300-copy standard, but 30 -copy and 3-copy standards did not produce a visible band.

\section{Histology}

Ichthyophonus sp. schizonts were visually identified in walleye pollock by histology; an individual's infection status varied depending on the tissue tested by histology (Table 6). When Ichthyophonus sp. was detected in a fish by both histology and qPCR, there was poor correlation between visually determined parasite density and estimated 18S rDNA copy number, with the exception of a few high-intensity infections in skeletal muscle (data not shown). Ichthyophonus sp. schizonts identified by histology in walleye pollock had similar size ranges in both skeletal muscle and heart tissues (Fig. 2). However, when comparing the median and average schizont size from all samples combined, schizonts from skeletal muscle were generally smaller than those examined in heart tissue (Fig. 2). An estimate of diameter from area returned similar results, where schizonts in skeletal muscle ranged from approximately 5 to $195 \mu \mathrm{m}$ with a mean of $41.7 \mu \mathrm{m}(\mathrm{SD}=35.8 ; \mathrm{N}=1187)$, while from all heart tissue examined, schizonts

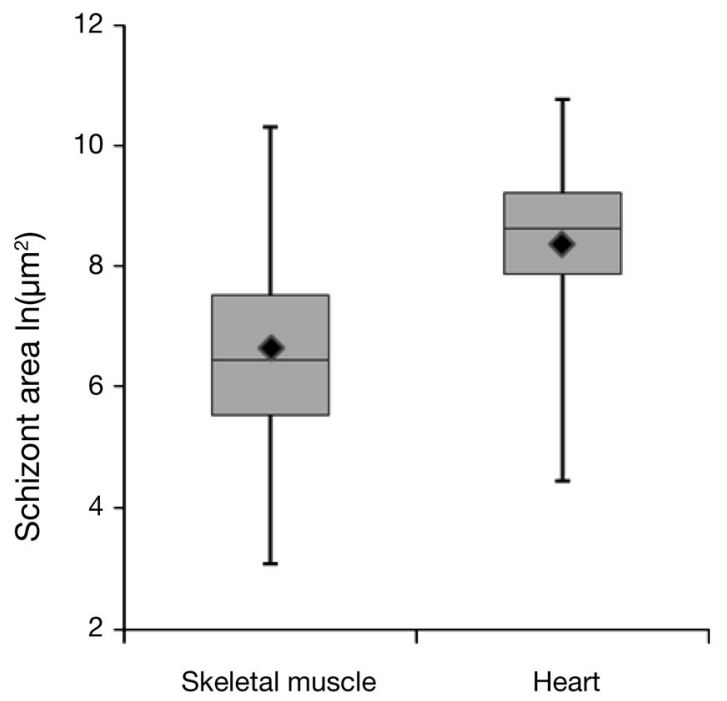

Fig. 2. Ichthyophonus sp. infecting Theragra chalcogramma. Degree of dispersion in size of all Ichthyophonus sp. schizonts measured from skeletal muscle $(\mathrm{N}=1187)$ and heart tissue $(\mathrm{N}=114)$ from walleye pollock histology samples (size represented as the natural log of schizont area in $\mu^{2}{ }^{2}$ ). Boxes represent quartiles; whisker ends represent the minimum and maximum area of all data; diamonds represent the mean area of all schizonts for each tissue type

ranged in size from 10 to $246 \mu \mathrm{m}$ with a mean of $88.5 \mu \mathrm{m}(\mathrm{SD}=46.5 ; \mathrm{N}=114)$. Likewise, when a comparison of schizont size and abundance between tissue types from an individual fish was possible, schizonts of smaller size were generally more frequent in skeletal muscle as compared to a smaller quantity of larger-sized schizonts in heart tissue (Fig. 3).

\section{DISCUSSION}

The qPCR assay developed in this study is a new tool for future research on Ichthyophonus spp.related issues, from prevalence estimations to transmission strategies. Through comprehensive validation of the assay, we found that the qPCR test was consistently specific for Ichthyophonus spp. DNA. DSp remained high either as a 2-tissue test (skeletal muscle and heart; Table 5) or a single tissue test (skeletal muscle or heart; Table 5), similar to the findings of Whipps et al. (2006) for the cPCR assay. Moreover, the evaluation of 3 components of ASp ensures confidence in positive results. This assay provides a more accurate estimate of prevalence than CPCR and histological methods for both tissue types tested (Table 6) while still allowing for chemical preservation of samples and long-term storage. Additionally, 


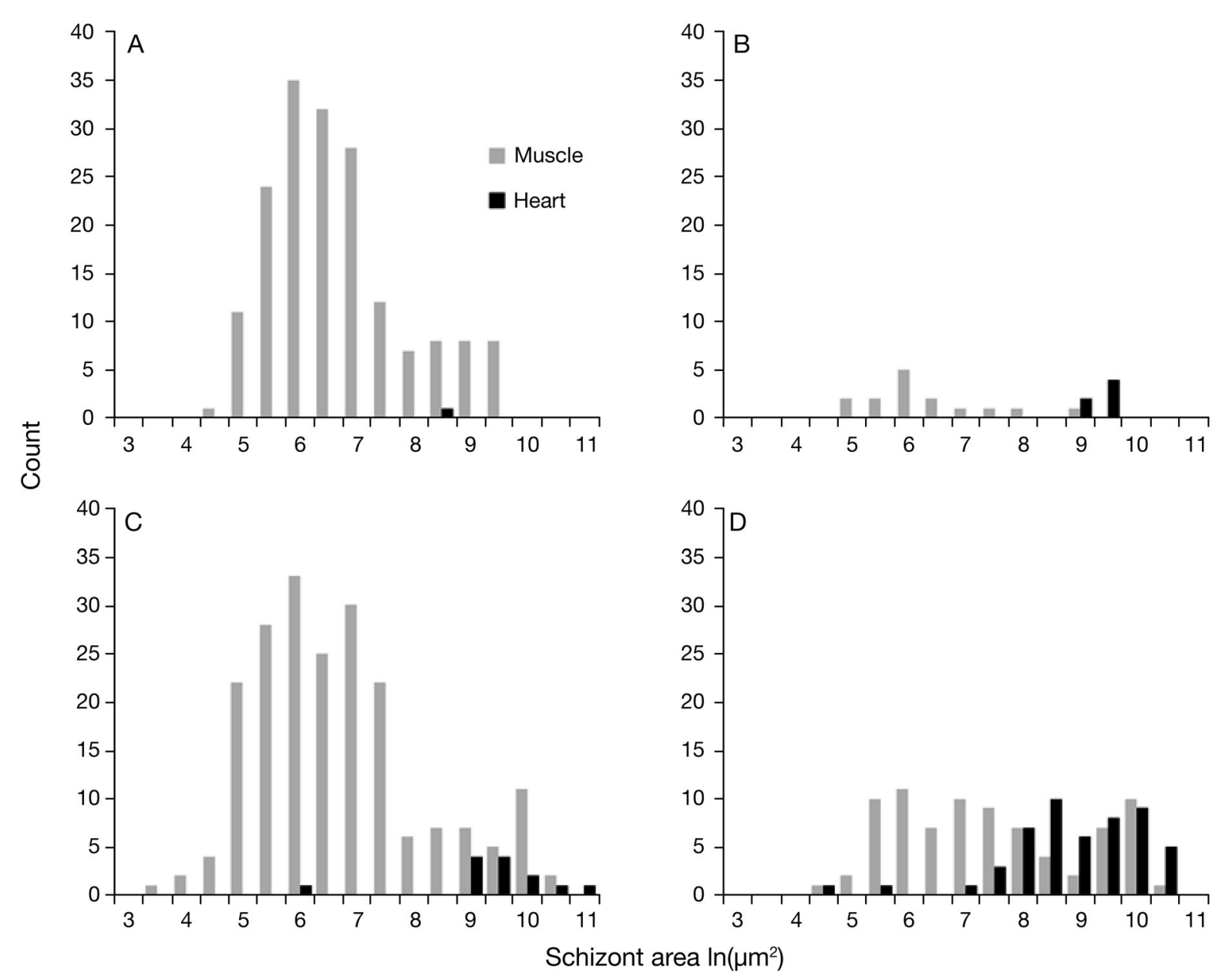

Fig. 3. Ichthyophonus sp. infecting Theragra chalcogramma. Count of Ichthyophonus sp. schizonts by size group ln(area in $\mu \mathrm{m}^{2}$ ) in skeletal muscle and heart tissue from 4 walleye pollock: (A) fish fork length $=43 \mathrm{~cm}$; $(\mathrm{B}-\mathrm{D})$ fish fork length $=50 \mathrm{~cm}$

at an individual sample level, qPCR proved more effective than cPCR for identifying Ichthyophonus sp. DNA at low concentrations (Fig. 1).

The 100-fold increase in ASe of qPCR over CPCR (Fig. 1) likely aids in the detection of light infections. This notion was reflected in the increase in minimum DSe for light, heavy, and all infections with qPCR (Table 5) as compared to cPCR (Whipps et al. 2006). However, the DSe of the qPCR assay varied greatly depending upon whether the fish had light or heavy Ichthyophonus sp. infection status, consistent with the cPCR assay evaluation (Whipps et al. 2006). DSe was high for both tissue types in both years for heavy infections, but decreased dramatically in fish with light infections (Table 5). The notable discrepancy in DSe between tissue types of light infections in 2007 may be due to variation in the quantity, size, and distribution of schizonts in skeletal muscle as compared to heart tissue as seen by histology (Figs. $2 \& 3$ ). To avoid missing light infections with the qPCR assay and to obtain the best estimate of Ichthyophonus spp. prevalence, it is recommended that at least 2 tissue types are collected for analysis, if costs permit (Tables 5 \& 6).

One benefit of PCR-based assays is the small amount of tissue necessary to test for parasite DNA presence in an individual. However, this benefit can become a limiting factor when the host individual is large and the parasite is unevenly distributed within the host or lacks specific tissue tropism. This problem regarding Ichthyophonus spp. detection has been well described by Kocan et al. (2011) in a 3-dimensional analysis of schizonts in Pacific herring skeletal muscle. Ichthyophonus spp. schizonts have variable distribution within host tissue as well as between individuals and host species, which likely contributes to differences in DSe among detection techniques (Kocan et al. 2011). To acquire the most accurate esti- 
mate of prevalence, it is important to identify the best target tissue for different hosts. For example, in Chinook salmon, heart samples produced more positive results by all detection methods (Whipps et al. 2006), while in walleye pollock, skeletal muscle samples produced more positive results by all detection methods (Table 6).

The qPCR assay for Ichthyophonus spp. DNA detection has been validated as described previously, but questions still remain surrounding its comparability to non-molecular detection methods for this parasite group. For example, comparing parasite quantity estimations from qPCR and histology presents a challenge considering that Ichthyophonus spp. are multinucleated organisms of various sizes containing various nuclei. These issues of uneven parasite size and distribution were apparent in this study, as the count of Ichthyophonus sp. schizonts $\mathrm{mm}^{-2}$ did not correlate with qPCR copy numbers. Additionally, it is uncertain whether the qPCR assay is comparable to in vitro culture, currently the most accurate technique for estimating prevalence of this parasite in fish populations (Kocan et al. 2011). In vitro culture was not compared to qPCR in this study due to issues with sample transportation from remote locations, but it is likely that many of the potential sources for detection error discussed by Whipps et al. (2006) and Kocan et al. (2011) also apply to qPCR due to inherent issues with the process of DNA extraction of small samples. To more fully assess the DSe and DSp of this qPCR assay relative to the diagnostic standard, a lab-based comparison of in vitro culture and qPCR on captive Pacific herring is currently underway.

In vitro culture may be the most sensitive method of Ichthyophonus spp. detection because of enhancement of the live parasite during sample storage (Kocan et al. 2011) and also, in part, due to the ability to use a large piece of starting material without the need to subsample after field collection, a routine practice in PCR-based assays and histological sectioning. Techniques with potential for enhancing qPCR DSe include pooling samples from different organs, homogenization of larger samples, and processing multiple subsamples. Some of these options could reduce costs over processing heart and skeletal muscle separately as described in this study, but these practices should be approached with caution as assay sensitivity could be affected by either target DNA dilution or PCR inhibition. For example, a false negative result could occur if Ichthyophonus spp. target DNA from one organ is diluted beyond the assay's limit of detection with non-target DNA from pooling. PCR inhibition could also affect assay sensitivity if pooled organs possess inhibitory factors; therefore assay application to other organs or blood (as a non-lethal method) would require additional testing. Although qPCR is not likely a replacement for in vitro culture estimation of Ichthyophonus spp. prevalence in fish populations, this assay does provide a more accurate estimate of prevalence than CPCR and histological methods when culture is not feasible (Table 6). The sample collection method and chemical preservation used in the qPCR assay also provides some flexibility in remote locations when long-term, temperature-controlled storage and shipment are not reliable or available, considering that live cultures of Ichthyophonus spp. must be kept cool.

Beyond basic Ichthyophonus spp. prevalence estimation, the qPCR assay could be used for a number of different types of applications in both wild host populations and captive laboratory experiments. For example, transmission of Ichthyophonus spp. to planktivorous hosts has not been defined, and researchers have suggested that the parasite could be acquired directly from the water or via a yet-tobe indentified invertebrate intermediate host (Hershberger et al. 2002). Ichthyophonus spp. cell forms within intermediate hosts or the environment could be small or appear morphologically different from the large multinucleate schizonts frequently observed in fish tissue. Therefore, Ichthyophonus spp. from these sample types could be misidentified or disregarded without DNA detection used in combination with other tests (i.e. in vitro culture followed by $\mathrm{cPCR}$ ). This new qPCR tool could be optimized to screen for DNA from members of the genus Ichthyophonus in zooplankton, water, sediment, and other samples in which axenic collection is not possible. A modified version of the qPCR protocol is currently being tested for use in mixed zooplankton samples, although as mentioned previously, the presence of inhibitors and modifications to DNA extraction methods could alter assay sensitivity. Additionally, qPCR may be useful in laboratory experiments where fish are infected by interperitoneal injection under controlled conditions. Inoculation doses can be challenging to estimate considering the highly variable size of Ichthyophonus spp. schizonts. By using qPCR to quantify gene copy number, the assay could prove useful in estimating and standardizing inoculation dose of Ichthyophonus spp., as well as aiding in the determination of infective units (P. Hershberger pers. comm.). 
Development and validation of this novel qPCR assay provides researchers a new tool for examining Ichthyophonus spp. and could be used for a variety of applications. Parasite DNA detection with qPCR may identify novel hosts and population trends, leading to a better understanding of Ichthyophonus spp. dynamics and range. While results from environmental samples could further our understanding of transmission and life history of this organism. Considering Ichthyophonus spp. are parasites of many commercially important fish species, use of this new assay could supply the industry with information to better manage product recovery, fish waste, and resources in the North Pacific as well as worldwide.

PCR-based assays are increasingly being applied as complements or alternatives to conventional pathogen detection techniques such as histology and in vitro culture (Yang \& Rothman 2004). Likewise, qPCR assays are rapidly replacing cPCR assays with advantages including rapid detection, quantification of gene copies, and the potential for increased sensitivity and specificity (Guimaraes et al. 2011). Although qPCR is widely used in pathogen detection (Klein 2002), it is essential that development of new assays include proper validation to ensure that the test meets or exceeds the sensitivity and specificity of existing detection methods, while being repeatable and appropriate for the application (OIE 2009).

Acknowledgements. We thank C. Shavey for assistance with the 2006-2007 field collections and sample processing. We are also grateful for the assistance of the RACE scientific crew with catch processing and the crews of the FVs 'Northwest Explorer' and 'Arcturus' with vessel gear operations. We greatly appreciate the technical lab assistance of the members of the Friedman laboratory at the University of Washington, especially C. Burge and S. White, as well as the image analysis efforts of T. Hollowed and technical consulting of P. Jensen. We appreciate the generosity of M. Cafaro and W. Marshall for providing various rare samples. Finally, we thank 3 anonymous reviewers for their constructive comments and suggestions that greatly improved the manuscript. Reference to trade names does not imply endorsement by the National Marine Fisheries Service, NOAA.

\section{LITERATURE CITED}

Applied Biosystems (2003) Tutorial \& troubleshooting: creating standard curves with genomic DNA or plasmid DNA templates for use in quantitative PCR. Available at www3.appliedbiosystems.com/cms/groups/mcb_ marketing/documents/generaldocuments/cms_042486. pdf

Burns MJ, Nixon GJ, Foy CA, Harris N (2005) Standardisation of data from real-time quantitative PCR methods evaluation of outliers and comparison of calibration curves. BMC Biotechnol 5:31
Burreson EM (2008) Misuse of PCR assay for diagnosis of mollusc protistan infections. Dis Aquat Org 80:81-83

Bustin SA, Benes V, Garson JA, Hellemans J and others (2009) The MIQE guidelines: minimum information for publication of quantitative real-time PCR experiments. Clin Chem 55:611-622

Criscione CD, Watral V, Whipps CM, Blouin MS, Jones SRM, Kent ML (2002) Ribosomal DNA sequences indicate isolated populations of Ichthyophonus hoferi in geographic sympatry in the north-eastern Pacific Ocean. J Fish Dis 25:575-582

> Eaton WD, Kent ML, Meyers TR (1991) Coccidia, X-cell pseudotumors and Ichthyophonus sp. infections in walleye pollock (Theregra chalcogramma) from Auke Bay, Alaska. J Wildl Dis 27:140-143

Guimaraes AM, Vieira RF, Poletto R, Vemulapalli R and others (2011) A quantitative TaqMan PCR assay for the detection of Mycoplasma suis. J Appl Microbiol 111: 417-425

Guy RA, Payment P, Krull UJ, Horgen PA (2003) Real-time PCR for quantification of Giardia and Cryptosporidium in environmental water samples and sewage. Appl Environ Microbiol 69:5178-5185

Hershberger PK, Stick K, Bui B, Carroll C and others (2002) Incidence of Ichthyophonus hoferi in Puget Sound fishes and its increase with age of Pacific herring. J Aquat Anim Health 14:50-56

Klein D (2002) Quantification using real-time PCR technology: applications and limitations. Trends Mol Med 8: 257-260

Kocan RM, Hershberger PK, Winton JR (2004) Ichthyophoniasis: an emerging disease of Chinook salmon in the Yukon River. J Aquat Anim Health 16:58-72

Kocan RM, Gregg JL, Hershberger PK (2010) Release of infectious cells from epidermal ulcers in Ichthyophonus sp.-infected Pacific herring (Clupea pallasii): evidence for multiple mechanisms of transmission. J Parasitol 96: 348-352

Kocan R, Dolan H, Hershberger P (2011) Diagnostic methodology is critical for accurately determining the prevalence of Ichthyophonus infections in wild fish populations. J Parasitol 97:344-348

Kohlmeyer J, Volkmann-Kohlmeyer B, Tsui CKM (2005) Fungi on Juncus roemerianus. 17. New ascomycetes and the hyphomycete genus Kolletes gen. nov. Bot Mar 48: 306-317

Kurochkin YV (1985) Applied and scientific aspects of marine parasitology. In: Hargis WJ Jr (ed) Parasitology and pathology of marine organisms of the world ocean. Tech Rep NMFS 25. NOAA, US Department of Commerce, Seattle, WA, p 15-18

Larkin MA, Blackshields G, Brown NP, Chenna R and others (2007) Clustal W and Clustal X version 2.0. Bioinformatics 23:2947-2948

> Le Roux F, Audemard C, Barnaud A, Berthe F (1999) DNA probes as potential tools for the detection of Marteilia refringens. Mar Biotechnol (NY) 1:588-597

Luna L (1968) Manual of histologic staining methods of the Armed Forces Institute of Pathology, 3rd edn. McGrawHill Book, New York, NY

> Marty GD, Freiberg EF, Meyers TR, Wilcock J, Farver TB, Hinton DE (1998) Viral hemorrhagic septicemia virus, Ichthyophonus hoferi, and other causes of morbidity in Pacific herring Clupea pallasi spawning in Prince William Sound, Alaska, USA. Dis Aquat Org 32:15-40 
McVicar AH (1982) Ichthyophonus infection of fish. In: Roberts RJ (ed) Microbial diseases of fish. Academic Press, London, p 243-269

McVicar AH (1999) Ichthyophonus and related organisms. In: Woo PTK, Bruno DW (eds) Fish diseases and disorders: viral, bacterial and fungal infections. CABI Publishing, New York, NY, p 661-687

Mellergaard S, Spanggaard B (1997) An Ichthyophonus hoferi epizootic in herring in the North Sea, the Skagerrak, the Kattegat and the Baltic Sea. Dis Aquat Org 28: 191-199

Mendoza L, Taylor JW, Ajello L (2002) The class Mesomycetozoea: a heterogeneous group of microorganisms at the animal-fungal boundary. Annu Rev Microbiol 56:315-344

- Nolan T, Hands RE, Ogunkolade W, Bustin SA (2006) SPUD: a quantitative PCR assay for the detection of inhibitors in nucleic acid preparations. Anal Biochem 351:308-310

OIE (World Organisation for Animal Health) (2009) Manual of diagnostic for aquatic animals. Chapter 1.1.2. Principles and methods of validation of diagnostic assays for infectious diseases. Office International des Epizooties, Paris

OIE (2010) Manual of diagnostic tests and vaccines for terrestrial animals. Chapter 1.1.4/5. Principles and methods of validation of diagnostic assays for infectious diseases. Office International des Epizooties, Paris

Patterson KR (1996) Modelling the impact of diseaseinduced mortality in an exploited population: the outbreak of the fungal parasite Ichthyophonus hoferi in the North Sea herring (Clupea harengus). Can J Fish Aquat Sci 53:2870-2887

Pfaffl MW (2004) Quantification strategies in real-time PCR. In: Bustin SA (ed) A-Z of quantitative PCR. International University Line, La Jolla, CA, p 87-112

Plehn M, Mulsow K (1911) Der Erreger der Taumelkrankheit der Salmoniden. Zentralbl Bakteriol Parasitenkd Infektionskrankh Hyg 59:63-68

Powles PM, Garnett DG, Ruggieri GD, Nigrelli RF (1968) Ichthyophonus infection in yellow-tail flounder (Limanda ferruginea) off Nova Scotia. J Fish Res Board Can 25: 597-598

Rahimian H (1998) Pathology and morphology of Ichthyophonus hoferi in naturally infected fishes off the Swedish west coast. Dis Aquat Org 34:109-123

Editorial responsibility: Dieter Steinhagen,

Hannover, Germany
Rahimian H, Thulin J (1996) Epizootiology of Ichthyophonus hoferi in herring populations off the Swedish west coast. Dis Aquat Org 27:187-195

Rand TG, White K, Cannone JJ, Gutell RR, Murphy CA, Ragan MA (2000) Ichthyophonus irregularis sp. nov. from the yellowtail flounder Limanda ferruginea from the Nova Scotia shelf. Dis Aquat Org 41:31-36

Rasmussen C, Purcell MK, Gregg JL, LaPatra SE, Winton JR, Hershberger PK (2010) Sequence analysis of the internal transcribed spacer (ITS) region reveals a novel clade of Ichthyophonus sp. from rainbow trout. Dis Aquat Org 89: 179-183

Rozen S, Skaletsky H (2000) Primer3 on the WWW for general users and for biologist programmers. Methods Mol Biol 132:365-386

Ruggieri GD, Nigrelli RF, Powles PM (1971) Epizootics in yellowtail flounder, Limanda ferruginea Storer, in the western North Atlantic caused by Ichthyophonus, an ubiquitous parasitic fungus. Zoologica (NY) 55: $57-61$

Sheehan DC, Hrapchak BB (1980) Theory and practice of histotechnology, 2nd edn. The C. V. Mosby Company, St. Louis, MO

Sindermann CJ (1958) An epizootic in Gulf of St. Lawrence fishes. Trans N Am Wildl Nat Resour Conf 23:349-360

Sindermann CJ, Chenoweth JF (1993) The fungal pathogen Ichthyophonus hoferi in sea herring Clupea harengus: a perspective from the western North Atlantic. ICES-CM 1993/F:41. ICES, Copenhagen

Spanggaard B, Skouboe P, Rossen L, Taylor JW (1996) Phylogenetic relationships of the intercellular fish pathogen Ichthyophonus hoferi and fungi, choanoflagellates and the rosette agent. Mar Biol 126:109-115

Stratagene (2004) Introduction to quantitative PCR: methods and application guide. Stratagene, La Jolla, CA

- Whipps CM, Burton T, Watral VG, St-Hilaire S, Kent ML (2006) Assessing the accuracy of a polymerase chain reaction test for Ichthyophonus hoferi in Yukon River Chinook salmon Oncorhynchus tshawytscha. Dis Aquat Org 68:141-147

Yang S, Rothman RE (2004) PCR-based diagnostics for infectious diseases: uses, limitations, and future applications in acute-care settings. Lancet Infect Dis 4:337-348

Submitted: September 10, 2012; Accepted: January 22, 2013 Proofs received from author(s): March 21, 2013 